\author{
ELŻBIETA KOTKOWSKA \\ Uniwersytet im. Adama Mickiewicza \\ Wydział Teologiczny
}

\title{
Dostrzegać niestworzoną miłość poprzez Prawdę, Dobro i Piękno w rozproszonym świecie, według Pawła Fłorenskiego
}

To Discern Uncreated Love through Truth, Good and Beauty in a Scattering World according to Pavel Florensky

Tak zwana «milość» poza Bogiem nie jest milościq, lecz jedynie naturalnym, kosmicznym zjawiskiem, które nie bardziej podlega bezwzględnej chrześcijańskiej ocenie anizeli fizjologiczne funkcje żoładka'.

Zadaniem niniejszego wprowadzenia jest próba odwiedzi na pytanie. Dlaczego warto sięgać do myśli nieżyjacego już filozofa i teologa prawosławnego o. Pawla Aleksandrowicza Florenskiego $?^{2}$ Dla autorki artykułu wynika to z potrzeby tropienia takich osiągnięć naukowych w teologii, które mają aspiracje do całościowego (holistycznego) ujęcia otaczającej nas rzeczywistości. Nie jest to sprawą łatwą, ponieważ ogrom wiedzy szczegółowej, którą trzeba ogarnąć, przytłacza niejednego naukowca ${ }^{3}$ pragnącego postrzegać świat jako całość z uwzględ-

${ }^{\prime}$ P. Florenski, Filar i podpora prawdy. Próba teodycei prawoslawnej $w$ dwunastu listach, Warszawa 2009, thum. J. Chmielewski, s. 75.

${ }^{2} \mathrm{~W}$ literaturze polskiej przyjęła się podwójna pisownia nazwiska o. Pawła - spotykamy zarówno Fłorenski jak i Florenski, w anglojęzycznej literaturze mamy pisownię Florensky.

${ }^{3}$ Por. K. Rahner, w przemówieniu pt. Doświadczenia katolickiego teologa, stwierdza z żalem na krótko przed swoją śmiercią: „A przecież nie wiem prawie nic z tego wszystkiego, co chętnie bym wiedział, wszystkie doświadczenia wszystkich nauk, sztuk i wydarzeń dziejowych mówią teologowi o Bogu, a pojedynczy teolog nie wie prawie nic o tych doświadczeniach. [...] A przecież ilekroć otwieram dowolne dzieło którejkolwiek z nowoczesnych nauk, wpadam jako teolog w niemałą panikę. Większości tego, co tam napisano, nie wiem, i w większości przypadków nie jestem w stanie dokładniej zrozumieć tego, co można tam przeczytać. I tak czuję się jako teolog w pewien sposób zdezawuowany. Uświadamiam sobie z przestrachem mdłą abstrakcyjność i pustkę moich pojęć teologicznych. Mówię: świat został stworzony przez Boga. Ale czym jest ten świat, o tym 
nieniem relacji transcendentnych. Zarówno Jan Paweł II jak i Benedykt XVI, przemawiając do przedstawicieli świata akademickiego $\mathrm{w}$ przestrzeni universitas, którą tworzą jednostki naukowe i wyższe uczelnie, zwracali uwagę na ludzką tęsknotę za wolnością i prawdą. Papież Benedykt XVI stwierdza w przemówieniu do przedstawicieli świat nauki w Pradze 2009 roku, że: Na tę właśnie tęsknotę próbuja odpowiedzieć: wiara religijna, różne sztuki, filozofia, teologia $i$ inne dyscypliny naukowe - każda zgodnie z wlasnq metoda, na plaszczyźnie zarówno bacznej refleksji, jak też i dobrej praktykit, Papież propaguje ideę formacji integralnej i przeciwstawia ją obserwowanemu rozproszeniu i relatywizacji świata wartości, która rozdziela świat wiary od świata rozumu. Benedykt XVI jednocześnie ma to na uwadze, że wzajemne relacje rozumu $i$ wiary prowadzą ku oświeceniu umystów i serc, co skutkuje ukierunkowaniem na życie cnotliwes Obaj papieże ostrzegają że jeżeli współczesne społeczeństwa wyrosłe na fundamencie Biblii i kultury świata grecko-rzymskiego oddzielą się od swoich korzeni, to staną w obliczu coraz silniejszej relatywizacji i rozproszenia prawdy oraz hierarchii wartości etycznych, moralnych, z coraz większym trudem będq rozpoznawaty to, co prawdziwe, szlachetne $i$ dobre ${ }^{6}$.

Przyczyn relatywizmu, rozproszenia sytemu i hierarchii wartości, zaniku odnoszenia działań ludzi nauki do przyjętych norm etycznych i moralnych, można rozpatrywać w wielu aspektach: psychologicznym, kulturowym, społecznym, globalizacyjnym czy też filozoficznym, etycznym, moralnym. Nie bez uzasadnienia wydaje się hipoteza, iż o. Paweł Aleksandrowicz Fłorenski ${ }^{7}$, poznając relatywistyczną teorię Einsteina przewidywał jej skutki nie tylko dla nauki, ale i dla kultury oraz dla kształtowania się nowoczesnych światopoglądów. Można przyjąć, iż rozpoczął studia teologiczne po to, by stworzyć całościową wizję świata jako stworzenia pochodzącego z miłości Boga. Miłości, która przejawia się w świecie stworzonym poprzez Prawdę, Piękno i Dobro rozumiane jako metafi-

nie wiem prawie nic, i dlatego pojęcie stworzenia pozostaje dziwnie puste". w: Praeceptores. Teologia i teologowie języka niemieckiego, red. E. Piotrowski, T. Węclawski, Poznań 2005, s. 230231 ; publikowany również w: „Znak” 441 (2), 1992, s. 72-82.

"Przemówienie Benedykta XVI w czasie pielgrzymki do Czech wygloszone do przedstawicieli tamtejszego świata naukowego. Przemówienie Benedykta XVI wygloszone podczas spotkania z przedstawicielami czeskiego świata akademickiego 27 września 2009 roku, w: Ekai, Biblioteka, [online], [dostęp 29.09.2009], dostępne w Internecie, http://ekai.pl/biblioteka/dokumenty/x 769/przemowienie-benedykta-xvi-wygloszone-podczas-spotkania-z-przedstawicielami-czeskiego-swiataakademickiego-wrzesnia-roku/.

${ }^{5}$ Tamże.

${ }^{6}$ Tamże. To, co prawdziwe, szlachetne i dobre ma bezpośrednie odniesienie to wprowadzonej przez Platona triady, określającej byt: Dobro, Prawda i Piękno.

${ }^{7}$ Ojciec Pawel Aleksandrowicz Fłorenski jako matematyk i filozof poznal i kompetentnie działał w obu tych dziedzinach, by ostatecznie podjąć decyzję o studiach teologicznych. Jego krótki życiorys został przedstawiony na końcu artykułu w nocie biograficznej. 
zyczna triada ${ }^{8}$. Jest to triada jawiąca nie-stworzoną Miłość Boga w świecie. Tą problematyką o. Paweł zajął się w swoim głównym dziele teologiczno-filozficzпмт Столп и утверждение истины. Опыт православной теодиции в двенадиати письмах, wydanym w Moskwie 1914 roku?.

Współcześnie teologowie, jak również filozofowie, stają przed zadaniem poszukiwania nowych wizji, nie tylko uwzględniających osiągnięcia nauk przyrodniczych, ale również dążących do połączenia w jedną spójną całość trwałych niezmiennych prawd $z$ ciagła zmiennością i nieokreślonością sytuacyjną ${ }^{10}$. Sprawa w teologii jest ważna i poważna, ponieważ interpretację relacji stworzenia do Stwórcy w przeszłości dość często interpretowano wykorzystując wielką metafizykę substancji i przypadłości ${ }^{11}$. Spotykamy jednak też teologów, którzy nie związali się z tym nurtem. Trudno wymienić wszystkich, niech jako przykład posłuży przypomnienie postaci takich jak: Jan Szkot Eriugena, św. Bonawentura, bł. Jan Duns Szkot, Mikołaj z Kuzy i na koniec Hans Urs von Balthasar. Ich wizje teologiczne mogą przyczynić się współcześnie do poszukiwania takiej teologii, która stałość i niezmienność Boga zinterpretuje w innym języku niż tym związanym z filozofią Arystotelesa.

Rosyjski uczony, o. Paweł Aleksandrowicz Fłorenski najczęściej bywa kojarzony $\mathrm{z}$ teoretycznym opracowaniem $\mathrm{i}$ analizą sztuki cerkiewnej. Jednak, jako absolwent matematyki i filozofii Uniwersytetu Moskiewskiego, a potem prawosławnej uczelni duchownej w Siergiejew Posad, postanowił przedstawić swoją wizję syntezy nauk i teologii osadzoną i wypływającą ze wspólnoty Kościoła, silnie odwołującą się do Ojców Kościoła pierwszych wieków. W skrócie można powiedzieć, że teologia o. Pawła oparta jest w swych fundamentach na Biblii, a metodologicznie wykorzystuje wypracowane w czasie pierwszych soborów niepodzielonego Kościoła pojęcia filozoficzne. Ojciec Paweł nie sięga do metafizyki wypracowanej w zachodniej myśli filozoficznej, bliżsi mu są w tej przestrzeni tacy teologowie jak Grzegorz z Nyssy, Maksym Wyznawca, Jan Szkot Eriugena i Mikołaj z Kuzy czy niedaleki mu duchowo, choć nieznany, Hans Urs von Bal-

${ }^{8}$ Paweł A. Fłorenski w liście czwartym swego głównego teologicznego dzieła pisze: „«Prawda, Dobro, Piękno». Ta metafizyczna triada nie mieści w sobie trzech zasad, lecz jedną. To jedno i to samo życie duchowe, ale rozpatrywane pod różnymi kątami”. Filar..., dz. cyt., s. 64. Dokładniejszą analizą tego fragmentu zajmiemy się w dalszej części artykułu.

${ }^{9}$ Stolp $i$ utwierżdienije istiny. Opyt prawosławnoj teodicii $w$ dwienadcati pismach, wydanie polskie, Filar.... dz. cyt.

${ }^{10}$ Jak bardzo trudne jest to zadanie, warto przypomnieć cytowany już fragment wypowiedzi o. K. Rahnera, por. przypis 3.

"Dotyczy to oczywiście tych nurtów teologii Kościoła rzymskokatolickiego, które u swych podstaw mniej lub bardzie świadomie przyjmują filozoficzne podstawy teologii $w$ duchu św. Tomasza z Akwinu. Por. wywód o. Pawła na ten temat, Filar..., dz. cyt., s. 42-43. 
thasar ${ }^{12}$, natomiast wśród filozofów bliżsi mu są Henri Bergson, Alfred North Whitehead, Martin Heidegger ${ }^{13}$.

Podsumowując: dlaczego warto odwołać się do myśli teologiczno-filozoficznej o. Pawła Aleksandrowicza Fłorenskiego? Na pierwszy plan wysuwają następujące konkluzje:

- Potrafił przewidzieć narastające rozproszenie i relatywizację w pojmowaniu i przedstawianiu wartości transcendentalnych bytu takich jak, Prawda, Dobro i Piękno.

- Sięgał do filozofii pierwszej i próbował odnaleźć pierwotną jedność w zmiennym, rozproszonym i antynomicznym świecie.

- Rozpocząl poszukiwanie metod dających próby rozwiązań, które połączyłyby osiagnięcia i punkty widzenia filozofii i nauk przyrodniczych z perspektywy teologii.

- W obecnych czasach warte jest pokreślenia, że jest on świadkiem, który w czasach totalitaryzmu sowieckiego walczył całym swoim życiem duchowym i naukowym, aż po śmierć, o hierarchię wartości i widzenie stworzenia $\mathrm{z}$ odniesieniem do niestworzonej miłości Boga.

\section{WSPÓŁISTOTNOŚĆ - ÓHoov́oเov}

Finis amoris, ut duo unum fiant ${ }^{14}$.

Teologia o. Pawła Aleksandrowicza Fłorenskiego jest teologią trynitarną ${ }^{15}$, ze szczególnym uwzględnieniem i wszystkimi konsekwencjami, jakie niesie w sobie przyjęcie przez 318 Ojców soborowych w Nicejskim Wyznaniu Wiary nie-bi-

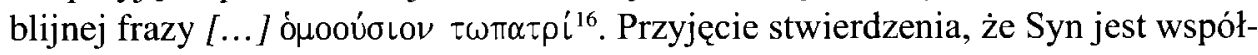

${ }^{12}$ Por. Z.J. Kijas. Homo creatus est. Ekumeniczne studium antropologii Pawla A. Florenskiego $(† 1937)$ i Hansa Ursa von Bathasara $(\dagger 1988)$, Kraków 1996, autor zestawił i krytycznie porównal antropologię Hansa Ursa von Bathasara $z$ dynamiczną antropologią ojca P. Fłorenskiego.

${ }^{13}$ Por. obszerne przypisy o. Pawła w: Filar..., dz. cyt., oraz R. Slesinski, Pavel Florensky: A Metaphysics of Love. New York. 1984.

${ }^{14}$ Celem mitości jest, by dwoje stało sie jednym. Filar..., dz. cyt., s. 7.

${ }^{15}$ Zob. T. Špidlík, Myśl rosyjska. Inna wizja czlowieka, thum. J. Dembska, Warszawa 2000. s. 67-72; P. Przesmycki, Świadek czystego światla, „W drodze” nr 1, 2002, [online], [dostęp 10.10.2009], dostępne: http:/www.mateusz.pl/wdrodze/nr341/05-wdr.htm

${ }^{16}$ Wyznanie wiary 318 Ojców, w: Dokumenty Soborów Powszechnych: tekst grecki, lacinski. polski. (325-787), t. 1, oprac. A. Baron, H. Pietras, Kraków 2005, s. 24. 
istotny Ojcu co do bóstwa, następnie dookreślenie na Soborze Chalcedońskim, że co do człowieczeństwa Syn Boży jest współistotny nam ${ }^{17}$, jest aksjomatycznym założeniem dynamicznej wizji stworzenia i jego relacji do Boga $\mathrm{w}$ rozumieniu o. Pawła A. Fłorenskiego. Rosyjski uczony określa swoją filozofię i teologię jako homoouzjańską ${ }^{18}$, czyli opartą na biblijnej i filozoficznej interpretacji fragmentu z Ewangelii św. Mateusza. Wszystko przekazal Mi Ojciec mój. Nikt też nie zna Syna, tylko Ojciec, ani Ojca nikt nie zna, tylko Syn, i ten, komu Syn zechce objawić. Przyjdźcie do Mnie wszyscy, którzy utrudzeni i obciażeni jesteście, a Ja was pokrzepię. Weźcie moje jarzmo na siebie i uczcie się ode Mnie, bo jestem cichy $i$ pokorny sercem, a znajdziecie ukojenie dla dusz waszych. Albowiem jarzmo moje jest stodkie, a moje brzemię lekkie (Mt 11,27-30).

W rozumieniu o. Pawła przesłanie Mateuszowej perykopy niesie w sobie znaczenie teoretyczno-poznawcze, gnozeologiczne ${ }^{19}$, oparte nie tylko na dyktaturze dociekań logicznych, ale uwzględniające również świat intuicji, rozważań i kontemplacji duchowych przeżyć mistycznych, czyli całość życia ${ }^{20}$. W swoich dociekaniach rosyjski uczony na pierwszym miejscu stawia i odwołuje się do ludzkiego doświadczenia ${ }^{21}$, ponieważ istnienia stworzenia nie da się wywieść z jakichkolwiek logicznych przesłanek. Pytając o podstawę, początek i sposób istnienia tego, co jest, odwraca rozumowanie tak charakterystyczne dla filozofii Zachodu i rozpatruje pytania: W jaki sposób Boża Prawda jawi się ludzkiemu intelektowi? Jak ludzkie bycie może stać się dobrem, prawdq i pięknem? ${ }^{22} \mathrm{Nie}$

${ }^{17}$ Orzeczenie Soboru Chalcedońskiego stwierdza: „Zgodnie ze świętymi Ojcami, wszyscy jed-

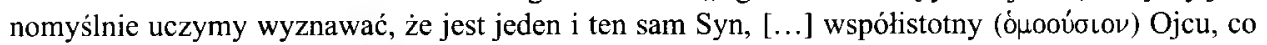
do Bóstwa i współistotny (óuooúotov) nam, co do człowieczeństwa", w: Dokumenty Soborów Powszechnych: dz. cyt., s. 223.

${ }^{18} \mathrm{P}$. Fłorenski wyraźnie rozróżnia między rozumieniem rzeczywistości stworzonej jako homoiouzjańskiej, czyli tylko rozpatrującej podobieństwo (a nie współistotność) a rzeczywistością rozpatrywana jako homoouzjańską. Por. V. List czwarty: Światto prawdy, w: Filar..., dz. cyt. s. $62-$ 89; M. Losski, Historia filozofii rosyjskiej, thum. H. Paprocki, Kęty 2000, s. 202-203; 211-212; 457-458; R. Slesinski, Pavel Florensky: A Metaphysics of Love, dz. cyt., 51-76; 121-138; D. Bruncz, Między niebem a ziemiq - Bóg i człowiek w teologicznej myśli prawoslawia - część II [online], [dostępne 10.10.2009], dostępne: http://www.magazyn.ekumenizm.pl/article.php?story $=20030121024111140$

${ }^{19}$ Filar..., dz. cyt., s. 17.

${ }^{20}$ Według o. Pawła: „Życie jest nieskończenie bogatsze od intelektualnej definicji, i dlatego żadna formułą nie może zawierać w sobie «całej» pełni życia”, Filar..., s. dz. cyt., 121.

${ }^{21}$ Już sama kompozycja jego głównego dzieła w formie listów do przyjaciela z sugestywnymi opisami przyrody i sytuacji egzystencjalnej piszącego wskazują, jak bardzo o. Paweł doceniał ludzkie doświadczenia jako kategorię badawczą.

${ }^{22}$ Paweł A. Fłorenski znał dzieła W. Jamesa, prekursora analizy ludzkiego doświadczenia w dociekaniach filozoficznych i religijnych. W teologii zachodniej nurt ten został doceniony po Soborze Watykańskim Il, por. Filar..., dz. cyt., s. 505; E. Kotkowska, Zwrot ku doświadczeniu w teologii XX w., w: Wstęp do teologii. Materiaty do ćwiczeń, red. tejże, Poznań 2007, s. 11-22. 
samo bycie jest dla niego problemem, ale jak ostateczna transcendentna racja, odkrywana w Bogu, który jest miłością, jawi się nam ludziom poprzez Dobro, Piękno i Prawdę doświadczanego istnienia.

Ostatecznie można stwierdzić, że teologia o. Pawła jest trynitologiczna i homoouzjańska aż po zawołanie: Albo trójjedyny chrześcijański Bóg, albo śmierć $w$ szaleństwie ${ }^{23}$. Nie jest to tylko emfatyczne zawołanie, jest to stwierdzenie ontologicznie mocne. Poznawcze działanie omawianej perykopy (Mt 11,27-30)

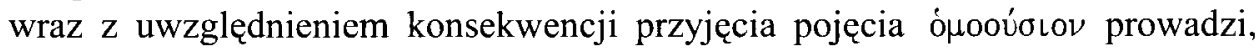
według o. Pawła, do oświecenia umysłów $i \operatorname{serc}^{24}$, by odwołać się do wspomnianych na wstępie słów Benedykta XVI. Trudno przedstawić w tym artykule całość wywodów uzasadniających przyjęcie argumentów meta-logicznych w filozofii o. Pawła A. Fłorenskiego ${ }^{25}$. Warto jednak zdać sobie sprawę, iż zawsze precyzyjnie określał, jak każdy matematyk, dziedzinę, warunki brzegowe, przyjęte aksjomaty i zakres ich stosowalności w każdym z obszarów działań poznawczych, czy to logiki formalnej, dyskursu dialektycznego, naukowego sceptycyzmu, czy też w ponad-intelektualnych badaniach żywego doświadczenia religijnego $\mathrm{w}$ relacji do wspólnoty ${ }^{26}$. Ściśle precyzował też ograniczenia metodologiczne w każdym z obszarów, ukazując przyczyny, dla których wychodzi poza zakres stosowalności danych metod.

Ojciec Paweł A. Fłorenski szukał takiej metody w teologii, wybierał takie przemyślenia filozoficzne, które prowadziły go ku uchwyceniu pierwotnej niezłożoności w pokawałkowanym, rozproszonym, antynomicznym istnieniu. Szukał możliwości opisu rzeczywistości, który nie zniweluje dynamiki i zmienności

${ }^{23}$ I dodaje: Tertium non datur, Filar..., s. 56, por. D. Nicholl, Pawel Florenski. Uczony męczennik, .Znak“ z. 10, 2005, s. 75-80.

${ }^{24}$ Por. przypis 5.

${ }^{25}$ Dla o. Pawła oczywistym jest przyjęcie rzeczywistości ponadrozumowej, meta-intelektualnej, ponieważ ona daje nadzieję. W liście szóstym zatytułowanym Sprzeczność stwierdza: „Jedynie w chwili oświecenia rozumu przez laskę sprzeczności te [obserwowane w ludzkim doświadczaniu świata i relacji międzyludzkich] przestają istnieć. Ale dochodzi się do tego nie w intelektualny, lecz ponad-intelektualny sposób. Filar..., dz. cyt., s. 133. Zasady przyjęte przez rosyjskiego myśliciela omówione zostały w oprócz wspomnianego listu szóstego, (s. 120-138) we wstępie Do czytelnika i trzech pierwszych listach zatytułowanych: Watpienie, Trójjednia, Światlo prawdy. Zajmuje się w nich uzasadnieniem przekroczenia prawa tożsamości genetycznej, by przyjąć prawo tożsamości numerycznej, które pozwala szukać pierwotnej jedności w tym, co z natury jest zmienne, uzasadnia metodę, dzięki której odpowiada na pytanie: „Jak to się dzieje, że, wielorakość czasowo-przestrzenna nie narusza tożsamości (człowieka)?" por. Filar.... dz. cyt., s. 43; a całe tło wywodów, s. 11-89.

${ }^{26}$ Człowiek jako warunek konieczny swojego istnienia potrzebuje drugiego, o. Paweł analizuje ten problem na przykładzie przyjaźni: „Owo objawienie [Miłości] dokonuje się w osobowej, szczerej miłości dwóch, w przyjaźni, kiedy kochający wstępnie, bez ascezy, przezwycięża samotożsamość, usuwa granice Ja, wychodzi w siebie i odnajduje swoje Ja w Ja innego - Przyjaciela. Przyjaźń jako tajemnicze narodziny Ty jest owym środowiskiem, w którym zaczyna objawiać sie Prawda". Filar.... dz. cyt., s. 310. 
otaczającej człowieka. Uznał zmienność i antynomiczność świata stworzonego jako nieusuwalne aksjomaty i właśnie dzięki nim pragnął dotrzeć do niezmiennych zasad, jakkolwiek i one jawią się mu jako ciągły życiodajny ruch Bożej miłości.

W swoich poszukiwaniach o. Paweł jako matematyk, filozof i teolog, uznał, że należy przekroczyć, wznieść się ponad statyczne prawo tożsamości $A \equiv A^{27}$, jak również przerwać nieskończony łańcuch samo-uzasadniających i niekończących się dyskursów dialektycznych na rzecz argumentu meta-intelektualnego. Tylko wtedy otwierają się nowe możliwości przed ludzkim poznaniem. Możliwy staje się opis wzajemnych dynamicznych relacji stworzeń, człowieka do człowieka, człowieka do świata, i dodatkowo - dzięki analizie pojęcia ónoov́øı v - otwiera się możliwość wejścia w Prawdę życia wewnętrznego Trójjedynego Boga. Rosyjski uczony włączył ludzką intuicję w obszar dociekań teologicznych i uznał, że bez tej prawdy - która jawi mu się poprzez nią, potwierdzoną przez życie Kościoła/Cerkwi - nie może żyć. Ostatecznie konkluduje, że z dwóch poglądów, których nie można dowieść, wybiera to, co daje nadzieję ${ }^{28}$. Jeżeli przyjmie się proponowane przez o. Pawła założenia oraz obszar stosowalności poszczególnych procesów poznawczych, to dalej czytelnik jego dzieł prowadzony jest $\mathrm{z} \dot{z} e-$ laznq konsekwencja logiki ludzkiego rozumowania ${ }^{29}$.

\section{ONTOLOGIA MIŁOŚCI}

Uczyniwszy wysilek w imię milości do Prawdy, wszedlem z Prawdq w osobisty żywy kontakt (niechętnie dodaje formalne: jeśli w ogóle istnieje). ${ }^{30}$

Pytając o relację stworzenia, a szczególnie człowieka do Boga o. Paweł Fłorenski zastanawia się nad kosmologicznymi koncepcjami, ale nie zatrzymuje się nad możliwością ich uzgodnienia z przesłaniem Biblii, sięga głębiej. Jego Próba

${ }^{27}$ Jest to prawo logiczno-matematycznej tożsamości. Por. P.A. Florenski, Pojęcie tożsamości $w$ logice matematycznej, w: tenże, Filar..., dz. cyt., s. 405-413. Przekroczenie opisanego prawa tożsamości rodzajowej skutkuje przyjęciem prawa tożsamości numerycznej i specyficznym dla Fłorenskiego opisem osoby: „Pojęcie tożsamości numerycznej nie przystaje do "wielu rzeczy»: rzecz może być wyłącznie 'podobna' albo 'niepodobna', ale nigdy - 'identyczna' albo 'nie identyczna'. Przeciwnie, o dwóch osobach nie można, w istocie, powiedzieć, że są 'podobne', lecz wyłącznie, że są 'tożsame' albo 'nie tożsame'. Dla osoby jako osoby możliwa jest albo tożsamość numeryczna, albo żadna". Filar..., dz. cyt., s. 67, oraz dalszy ciag artykułu paragraf Ekonomia mitości.

${ }^{28}$ Por. o. Pawel odwołuje się do poglądów Arnobiusza: ,[...] z dwóch nie dających się udowodnić rzeczy tę, która daje nam nadzieję, zawsze należy przedkładać nad tę, która nam jej nie daje", Filar..., dz. cyt., s. 58 oraz 505-506.

${ }^{29}$ Mikołaj Łosski, Historia filozofii rosyjskiej, dz. cyt., s. 202-204.

${ }^{30}$ Filar..., dz. cyt., s. 61 . 
teodycei prawoslawnej $w$ dwunastu listach to przede wszystkim apologia niestworzonej miłości Trójjedynego Boga, próba stworzenia filozofii pierwszej opartej na tym aksjomacie. Pierwotnym słowem Boga, primum dictum, w relacji do stworzenia jest miłość, wzajemna wszechogarniająca miłość Ojca, Syna i Ducha Świętego. Ona wylewa się jako porządek etyczny wszechświata, jako najpierwotniejsza podstawa tego, co istnieje. Jest to porządek miłości, który w koncepcji teologiczno-filozoficznej o. Pawła A. Fłorenskiego ujawnia się światu poprzez metafizyczną triadę Dobra, Prawdy i Piękna, których nie można rozpatrywać osobno, gdyż obrazują jedno i to samo 'życie duchowe' pod różnymi kątami ${ }^{31}$, a pełne poznanie prawdy możliwe jest tylko gdy do poznania intelektualnego dołączy się poznanie meta-intelektualne.

Ojciec Paweł zadaje sobie sprawę, że rozum ludzki, poznając otaczająca rzeczywistość, ze względów metodologicznych musi dokonywać redukcji podczas interpretacji otrzymywanych danych, innej w każdym z obszarów: teologii, metafizyki, nauk przyrodniczych. Dlatego filozoficzna, rozumowa spekulacja pytająca o to, co było $\dot{\epsilon} \nu \alpha \hat{\alpha} \rho \chi \bar{\eta}$, czy o status transcendentalnych właściwości bytu takich jak dobro, prawda i piękno, jest, według niego, szczególnym przypadkiem, ogólnego porządku z ontologicznie pojmowaną miłością. Natomiast pytania o prawa fizyczne działające w kosmosie od początku jego czasowego istnienia, domagają się jeszcze większej metodologicznej redukcji, by ten świat można było badać i rozpoznawać. Przedstawiciele filozofii i nauk matematyczno-przyrodniczych, w przekonaniu rosyjskiego teologa, powinni mieć świadomość szerokiego horyzontu, jaki daje im wizja świata z ontologicznie pierwszq milościq ${ }^{32}$, z jednej strony, a $\mathrm{z}$ drugiej powinni działać zgodnie z przyjętą metoda/metodami badanej dziedziny i nie przenosić bezkrytycznie schematów interpretacyjnych badanych przez nich obiektów na świat wartości ogólnych, a tym bardziej w przestrzeń ontologicznej miłości $i^{33}$. Tylko takie ujęcie wizji filozoficznych i szczegółowych badań w naukach przyrodniczych, o czym przekonuje o. Paweł, nie pozwoli na zagubienie tego, co spaja, co harmonizuje w perspektywie oglądu całości i celu istnienia. Tylko takie rozpatrywanie problemów pozwoli na poznanie

\footnotetext{
${ }^{31}$ Tamże, s. 64.
}

${ }^{32}$ Jan Paweł II doceniał próby całościowego widzenia świata o. Pawła. W swojej encyklice Fides et ratio wymienia go wśród innych wielkich myślicieli. „Przejawem owocnej relacji między filozofią a słowem Bożym są też śmiałe poszukiwania podjęte przez myślicieli bliższych nam w czasie, spośród których chciałbym [...] w kręgu kultury wschodniej uczonych formatu Władimira S. Solowjowa, Pawła A. Florenskiego, Piotra J. Czaadajewa, Wladimira N. Losskiego", (pkt. 74). Papież, podkreślił również, że chodzi mu pewien typ działań intelektualnych, niekoniecznie o wszystkie wnioski, do których ci uczeni doszli.

${ }_{33}$ Ojciec Paweł przeciwstawia się psychologicznemu ujęciu problemu miłości, uznając je za niewystarczające. „Dla uniknięcia nieporozumień konieczne wydaje się podkreślenie 'ontologizmu’ miłości, mającego historyczne korzenie w starożytnym realistycznym pojmowaniu życia”. Filar..., dz. cyt., s. 65 , por. też s. $70 \mathrm{nn}$. 
Boga-Prawdy. Każde inne działanie jest nieuzasadnionym działaniem zamykającym, wyznaczającym kres i granice ludzkim możliwościom poznawczym, prowadzi do zagubienia i dezorientacji.

Ojciec Paweł Fłorenski w swoich dociekaniach wychodzi od ludzkiego doświadczenia życia jako całości. Dlatego, w jego przekonaniu, objaśnienia przy pomocy praw ścisłej logiki czy definicji podających, co jest co, nie wyczerpują opisu rzeczywistości. Rosyjski teolog w pierwszych etapach przekonywania w swojej teodycei, problem istnienia Boga sformułował w trybie warunkowym. Jeśli jest Bóg - a stawalo się to dla mnie czymś oczywistym - to, z konieczności, musi On być absolutnq mitościq. Jednak milość nie jest 'cechq' Boga. [...] Bóg jest istota absolutna, dlatego że jest On substancjalnym aktem miłości, aktemsubstancja $q^{34}$.

Tryb warunkowy tego zdania był dla o. Pawła koniecznością metodologiczną, ponieważ poznanie teoretyczne (abstrakcyjne) uniemożliwia sformułowanie zdania: Bóg istnieje. Natomiast przejście do poznania praktycznego (konkretnego) w świat wiedzy intuicyjno-dyskursywnej powoduje, że warunkowość zdania Bóg istnie, topi się i rozpływa ${ }^{35}$.

Pozostaje teraz rozpatrzyć, w jaki sposób o. Paweł A. Fłorenski próbuje, na tyle na ile to możliwe, przybliżyć się do ku przyjęciu stwierdzenia, iż Bóg jest substancjalnym aktem milości, aktem-substancja ${ }^{36}$, czyli na początek, $\mathrm{w}$ jaki sposób Bóg Ojciec udziela siebie Synowi, ten udziela siebie Ojcu w Duchu Świętym. Na początek przytoczmy wywód o. Pawła uzasadniający korzyści poznawcze $\mathrm{z}$ przekroczenia prawa logicznej tożsamości $\mathrm{A}=\mathrm{A}$. Wywód ten pomógł teologowi, jakkolwiek nie używa imion osób Trójcy Przenajświętszej, uzasadnić jego homoouzjańską i opartą na perykopie św. Mateusza wizję tajemnicy Boga. $Z a-$ miast pustej, martwej i formalnej samo-tożsamości $" A=A »$, moca której A powinno samolubnie, pewnie, egoistycznie wykluczać wszelkie nie-A, otrzymaliśmy bogatq $w$ treść, pelnq życia, realnq samo-tożsamość A jako czegoś, co wiecznie siebie odrzucajac, $w$ swoim samo-odrzuceniu wiecznie siebie otrzymuje. Jeśli w pierwszym przypadku $A$ jest $A(A=A)$ jako następstwo wykluczenia $z$ niego wszystkiego (również jego samego $w$ jego konkretności!), to teraz $A$ jest $A$ poprzez potwierdzenie siebie jako nie-A, poprzez przyswojenie $i$ asymilację wszystkiego. Staje sie przez to zrozumiałe, jaki jest sam przez siebie dowodzony Podmiot i na czym polega owa dowodliwość, jeśli, rzecz jasna, Podmiot ów w ogóle

${ }^{34}$ Filar..., dz. cyt., s. 62.

${ }^{35}$ Ojciec P. Florenski zdaje sobie sprawę, że przejście od trybu warunkowego do pewności jest indywidualnym aktem woli, a nie samo-narzucajacą się procedurą wynikania. „To, co dla doświadczającego okazuje się wiedzą absolutną, dla teoretyka pozostaje wyłącznie przedłużeniem probabilizmu", tamże.

${ }^{36}$ Filar..., dz. cyt., s. 45, 62, 65. 
istnieje. Jest on taki, że jest $A$ i nie-A. Oznaczymy dla jasności nie-A przez $B$. $C z y m$ jest $B$ ? $B$ jest $B$, ale ono samo bytoby ślepym $B$, gdyby nie byto jednoczesnie nie-B. Czym jest nie-B? Gdyby bylo ono po prostu $A$, to $A$ i $B$ bylyby wówczas tożsame. $A$, będace $A$ i $B$, bytoby tylko jednym, prostym, czystym $A$, dokladnie tak samo jak i $B$. (Jak zobaczymy, w herezjologii odpowiada to modalizmowi, sabelianizmowi itp.). Ażeby nie bylo prostej tautologii $« A=A »$, ażeby byla realna równość " $A$ jest $A$, albowiem $A$ jest nie-A», konieczne jest, ażeby $B$ samo byto realnościa, tzn. ażeby $B$ byto jednocześnie $B$ i nie-B; to ostatnie, tzn. nie- $B$, dla większej jasności, oznaczymy przez $C$. Poprzez $C$ krag może zostać zamknięty, albowiem w jego «innym» $-w$ «nie-C» - A odnajduje siebie jako $A$. W B przestajac być $A, A$ od innego, ale nie od tego, do którego jest porównywane, tzn. nie od $C, w$ sposób zapośredniczony otrzymuje siebie, ale już jako coś «dowiedzionego», ustalonego. To samo odnosi się także do każdego z podmiotów $A, B, C$ w ich wzajemnych troistych stosunkach ${ }^{37}$.

Jakkolwiek dla kogoś nieoczytanego w literaturze dotyczącej logiki jest to język dość specyficzny, to opis ten można odnieść do treści pojęcia perychoreza trynitarna $^{38}$. Jest to próba wniknięcia w życie wewnętrzne Trójcy, która opiera się na przekonaniu, iż w Bogu trwa dynamiczna wymiana miłości, ponieważ tylko miłość może w tak doskonały sposób łączyć to, co jest oddzielone. To właśnie udzielająca się, od A (Bóg Ojciec) przez B (Syn) ku C (Duch Święty) i dalej ku A (Ojciec), miłość jest tym, co zostało określone jako akt-substancja, czyli istota Boga $\mathrm{i}$ podstawa stworzenia ${ }^{39}$. By bardziej tę myśl przybliżyć można stwierdzić, że podstawą istnienia tego, co stworzone są połączone i zharmonizowane $\mathrm{w}$ Bogu przeciwieństwa aktu-substancji, zmienności-stałości, dynamikibezruchu, poruszyciela-nieporuszonego, wydawania-przyjmowania. Ojciec Paweł A. Fłorenski opiera swój wywód na przekonaniu, że Bóg, albo Prawda, nie tylko posiada milość, lecz przede wszystkim «Bóg jest milościa» (por. 1J 4,8.16), a Syn jest współistotny (ónoovorov) Ojcu, co do bóstwa. Połączenie przesłania z Mateuszowej perykopy (Mt 11,27-30) oraz logiki, ku której uprawnia przekroczenie prawa samo-tożsamości, pozwala wejść człowiekowi w Prawdę Trójcy. Nie jest to prawda o Bogu w sensie dosłownym, ale proces modlitewnego przebywania w prawdzie Boga. W swoich dociekaniach o. Paweł kładzie nacisk na ciagłe dynamiczne wzajemne udzielanie się osób Boskich, to te wzajemne odniesienia, relacje wraz z podmiotami ich zaistnienia są nazwane aktem-substancja. To Ojciec wydaje siebie Synowi po to by w Duchu otrzymać siebie przez Syna; to Syn

${ }^{37}$ Filar..., dz. cyt., s. 44.

${ }^{38}$ Por. K. Rahner, H. Vorgrimler, Maty stownik teologiczny, thum. T. Mieszkowski, P. Pachciarek, Warszawa 1987, s. 323: G. O'Collins, E.G. Farrugia, Leksykon pojęć teologicznych i kościelnych $z$ indeksem angielsko-polskim, tłum. J. Ożóg, B. Żak, Kraków 2002, s. 130.

${ }^{39} \mathrm{Krag}$ udzielania miłości można rozpocząć od dowolnej osoby Boskiej, dla logiki wywodu nie ma to znaczenia. 
oddaje siebie Ojcu, by w Duchu otrzymać pełnię siebie. Jest to dynamika miłości, za przyczyną której jeden wydaje siebie drugiemu, by poprzez zapośredniczenie w trzecim otrzymać pełnię siebie, co określa o. Paweł w słowach: [...] trzy hipostazy czynia wiecznie jedna druga tym, czym wiecznie sq. Tylko w jedności Trzech każda hipostaza otrzymuje absolutne potwierdzenie, które ustanawia ja jako taka. Na zewnatrz Trzech nie ma żadnej z nich nie ma podmiotu Prawdy ${ }^{40}$. Tak, więc, o czym przekonuje o. Paweł A. Fłorenski, w historii zbawienia jawi się Trójjedna Prawda, Bóg z miłością sam wychodzi ku człowiekowi, aby człowiek mógł go poznać.

Nie jest specjalnie odkrywczym stwierdzenie, iż interpretacja antropologiczna, kim i jakim jest czlowiek zależy od przyjętego w danej teologii obrazu Boga. W szczególny sposób przekonuje o tym w swojej twórczości Ian G. Barbour ${ }^{41}$. Jeżeli o. Paweł w swoich dociekaniach nad życiem wewnętrznym Trójcy przyjmuje zasadę wspótistotności, to jest ona również zasadą odpowiedzi na pytanie, jak moge doświadczyć Trójjedynej milości $?^{42}$ Pierwsza narzucająca się odpowiedź wypływająca ze źródeł antropologii teologicznej prawosławia: człowiek najgłębiej rozpozna Boga w sobie, jako że został stworzony na Jego obraz i ma realizować w sobie Jego podobieństwo.

\section{EKONOMIA MIŁOŚCI}

Miłość prawdziwa jest wyjściem z tego, co empiryczne i przejściem do nowej rzeczywistości. ${ }^{43}$

Teologia i filozofia rosyjska w swojej refleksji opierają się na wizji człowieka, która jest głęboko osadzona biblijnie z wykorzystaniem osiagnięć związanych z wejściem orędzia chrześcijańskiego w świat kultury helleńskiej ${ }^{44}$. Wypracowana przez o. Pawła A. Fłorenskiego wizja człowieka nie odwołuje się do dokonań Boecjusza, czy Kartezjusza ${ }^{45}$, nie szukał on pełnej ścisłości w odpowiedzi na pytanie: Kim jest czlowiek?, ale zastanawiał się nad problemem: jak zachowuje

${ }^{40}$ Filar..., dz. cyt., s. 46.

${ }^{41}$ Mity, modele, paradygmaty. Studium porównawcze nauk przyrodniczych $i$ religii, tłum. M. Krośniak, Kraków 1984, s. 192-221.

${ }^{42}$ Por. przypis 22.

${ }^{43}$ Filar..., dz. cyt., s. 75.

${ }^{44}$ Por. Zdzisław J. Kijas, Homo Creatus est, dz. cyt., tenże, Czlowiek «obrazem i podobieństwem» Boga w prawostawnej teologii Pawta Florenskiego, „W nurcie franciszkańskim”, nr 4, 1995 s. 68-86; H. Pietras, Poczqtki teologii Kościola, Kraków 2000; J.N.D. Kelly, Początki doktryny chrześcijańskiej, thum. J. Mrukówna, Warszawa 1988.

${ }^{45}$ Pojęcie osoby, na określenie istoty ludzkiej, ksztaltowało się w pierwszych wiekach chrześcijaństwa odmiennie na Wschodzie i Zachodzie. W syntetyczny sposób ujmuje to zagadnienie jezuita, kardynał Tomáš Špidlík, Myśl rosyjska..., dz. cyt., szczególnie s. 22-31. 
on tożsamość? przy ciągłej zmienności w sobie jak i wobec warunków zewnętrznych. Rosyjski uczony konkluduje: Danie pojęcia osoby nie jest możliwe, albowiem tym wtaśnie różni się ona od rzeczy, że, w przeciwieństwie do tej ostatniej, podlegajacej pojęciu $i$ dlatego 'zrozumiatej', jest ona 'niezrozumiała', przekracza granice wszelkiego pojeccia, jest transcendentna w stosunku do każdego poję$\mathrm{cia}^{46}$. Ojciec Paweł w duchu filozofii i teologii rosyjskiej przyjmuje definicję osoby-istnienia otwartego ${ }^{47} \mathrm{~W}$ postaci niedookreślonego ostatecznie opisu, jako że człowiek przed Bogiem jest tym, który w ciagłym procesie zmian staje się tym, czym sam Bóg chce, aby się stał ${ }^{48}$. Odpowiedź na pytanie o status ontyczny człowieka jest refleksją nad podstawowym założeniem antropologii Kościoła Wschodniego, jak człowiek jest obrazem Boga i jak staje jego podobieństwem w procesie dochodzenia do bycia przebóstwionym ${ }^{49}$, a jest to proces dojrzewania w Duchu ${ }^{50}$.

Ojciec Paweł przekonuje, iż dynamika wewnętrznego życia Trójjedynego poprzez miłość, która musi się udzielać i jest pierwszą zasadą świata stworzonego, odnosi się również do człowieka. Człowieka, który będąc obrazem Boga odzwierciedla w sobie pełnię Boskiego życia. Oczywiście na tyle, na ile całość

${ }^{46}$ Ojciec Paweł podkreśla, iż wprowadzone przez niego pojęcie tożsamości numerycznej, zastosowane $\mathrm{w}$ opisie osoby, jest $\mathrm{z}$ zasady niedookreślone, $\mathrm{w}$ ciągu dalszym przytoczonego cytatu stwierdza, że poznanie osoby może się dokonywać tylko na sposób symboliczny - oczywiście przy platońskim rozumieniu symbolu, jako realnym uczestnictwie tego, co jest w symbolu przedstawiane. Zob. ciąg dalszy: „Można co najwyżej stworzyć «symbol» podstawowej charakterystyki osoby albo «znak», «słowo», i nie definiując go, wprowadzić formalnie do systemu innych słów, i uczynić tak, ażeby poddawało się ono ogólnym operacjom nad symbolami, 'jak gdyby' rzeczywiście było znakiem pojęcia. Co się tyczy treści owego symbolu, to nie może być ona intelektualna, lecz jedynie bezpośrednio przeżywana $w$ doświadczeniu samo-tożsamości, w aktywnym samo-tworzeniu osoby, w tożsamości duchowej samo-świadomości. Oto, dlaczego termin 'tożsamość numeryczna' jest tyko symbolem, a nie pojęciem". Filar..., dz. cyt., s. 70.

${ }^{47}$ Ojciec P. Fłorenski w swoje pracy polemizuje z monadologią G.W. Leibniza. Por. Filar..., dz. cyt., s. 65,69 .

${ }^{48}$ Można powiedzieć, iż: „Według, opierających się na Piśmie Świętymi i filozofii Platona Ojców Kościoła, osoba to nie to, co mam, co jest, ale to, co się staje, co będzie pomiędzy tym, co indywidualne a tym, co wspólne. W swoim stawaniu człowiek jest zawsze czymś akcydentalnym, istniejącym dzięki łasce Boga. Można go określić w danym momencie, który jest związany z poprzednimi takimi momentami, ale nie jest możliwe ogarnięcie go jako całości. Zawsze poznajemy istotę ludzką jako część całości i na tyle, na ile całość może być realizowana przez części”. E. Kotkowska, Podstawy sprzeciwu wobec form wykluczenia spolecznego, wedlug Simone Weil, „Społeczeństwo i Kościół”. Państwo i Kościót wobec aktualnych form wykluczenia i marginalizacji ludzi, red. Józef Baniak, t. 3, Poznań 2006, s. 205-206.

${ }^{49}$ Historiozbawczą antropologię obrazu i podobieństwa streszcza w jednym zdaniu złota reguła patrystyczna, iż Chrystus stał się człowiekiem, byśmy my mogli stać się bogami. J. Naumowicz, w artykule: Wcielenie Boga i zbawienie czlowieka. Zlota regula soteriologii patrystycznej. ., Warszawskie Studia Teologiczne" nr 13, 2000, s. 17-30, przedstawia autorów tegoż stwierdzenia i podaje bibliografię zagadnienia.

${ }^{50}$ Filar..., dz. cyt., s. 70, J. Naumowicz, Wcielenie Boga i zbawienie czlowieka..., dz. cyt., s. 26. 
może być odzwierciedlona przez części. Natomiast poprzez ideę podobieństwa myśl rosyjska opisuje proces realizacji w czasie ludzkiego dążenia do bycia przebóstwionym. Dla o. Pawła ponownie jest to teologiczno-filozoficzna interpretacja perykopy z Ewangelii św. Mateusza, a szczególnie jej drugiej części: Wszystko przekazal Mi Ojciec mój. Nikt też nie zna Syna, tylko Ojciec, ani Ojca nikt nie zna, tylko Syn, i ten, komu Syn zechce objawić. Przyjdźcie do Mnie wszyscy, którzy utrudzeni i obciqżeni jesteście, a Ja was pokrzepię. Weźcie moje jarzmo na siebie i uczcie się ode Mnie, bo jestem cichy i pokorny sercem, a znajdziecie ukojenie dla dusz waszych. Albowiem jarzmo moje jest stodkie, a moje brzemię lekkie (Mt 11,27-30).

Ojciec Paweł swoją teologię opiera na szukaniu racji pytania, najdalej jak tylko rozum ludzki oświecony prawdą Objawienia potrafi pytać, jakim jawi się czlowiek $w$ relacji do Boga? Boga, który zawsze, jako pierwszy wychodzi ku człowiekowi, i to nie abstrakcyjnemu filozoficznemu fenomenowi, ale człowiekowi, który trudzi się, jest obciążony troskami, czy cierpieniem ponad miarę. W nauczaniu o. Pawła ku takiemu człowiekowi, przeżywającemu swoje antynomiczne tu i teraz w pocie czola i bólach rodzenia ( $\mathrm{Rdz} 3,16-17)$, Trójjedyny Bóg zwraca się miłością i takim człowiekiem się cieszy, jakkolwiek odrzuca jego grzech. Przedstawione przekonanie przebija przez słowa o. Pawła: Bóg, znajacy mnie jako swoje stworzenie; kochajacy mnie przez Syna jako swój «obraz», jako swojego Syna; cieszacy się mna w Duchu Świętym jako swoim "podobieństwem», aktywnie zna, kocha i cieszy się mnq, albowiem jestem Mu dany $^{51}$. Bóg, poprzez swoją miłość skierowaną przez Syna w Duchu ku stworzeniu poznaje człowieka, a w jaki sposób człowiek i Bóg poznają siebie we wzajemnej relacji miłości? Jak można opisać to poznanie $-\mathrm{z}$ jednej strony doskonałe, gdy podmiotem poznającym jest Trójjedyny Bóg, z drugiej strony cząstkowe, niepełne, gdy podmiotem poznającym jest człowiek-indywiduum, ale zakorzenione we wspólnocie ${ }^{52}$ ?

Ojciec Pawel, którego filozofia i teologia są osadzone w filozofii Platona, jest przedstawicielem poglądu, że to, co poznajemy, w pełni poznajemy dzięki intuicji, która jest bezpośredniq kontemplacja żywej rzeczywistości, takq jakq ona jest w sobie $e^{53}$, by zacytować rosyjskiego filozofa Mikołaja Łosskiego. Rzeczywistość poznajemy, według przedstawicieli filozofii rosyjskiej, dzięki aktowi wewnętrz-

${ }^{51}$ Filar..., dz. cyt., s. 65.

${ }^{52}$ Ojciec Paweł nie przyjmuje poglądów filozoficznych G.W. Leibniza interpretujących człowieka jako zamkniętą monadę ani wszystkich tych nurtów filozoficznych Europy Zachodniej, które doprowadzily do skrajnego liberalizmu i indywidualizmu oraz atomizacji życia spolecznego. Czlowiek jest dla niego koniecznie wspólnotowy - dokładniejszy opis tego zagadnienia wykracza poza ramy tego artykułu.

${ }^{53}$ M. Łosski, Historia filozofii rosyjskiej, dz. cyt., s. 201. 
nego zjednoczenia poznawanego $\mathrm{z}$ poznawanym ${ }^{54}$. Jest to możliwe dzięki przyjętemu przekonaniu o współistotności ${ }^{55}$ rzeczywistości Boskiej Osób Trójcy i współistotności rzeczywistości ludzkiej w Synu Bożym z ludźmi. Są to przesłanki, na podstawie których Paweł Fłorenski może stwierdzić: Prawdziwe poznanie Prawdy, tzn. przyswojenie sobie samej Prawdy jest zatem realnym wchodzeniem do wnętrza Bożej Trójjedni, a nie tylko idealnym dotykaniem jego formy zewnętrznej ${ }^{56}$. Rosyjski teolog stoi na stanowisku, że dzięki intuicji człowiek może realnie poznawać rzeczywistość transcendentną. Jest to poznanie nie w sensie intelektualnym, lecz poznanie $w$ sensie biblijnym ${ }^{57}$, stąd słowa o realnym wchodzeniu do wnętrza Bożej Trójcy. Ojciec Paweł jest wierny w tym względzie przesłaniu Ojców Kościoła, a szczególnie św. Grzegorza z Nyssy, z którego dzieła zamieścił cytat na stronie tytułowej Filaru i podpory Prawdy: wiedza staje się milościq ${ }^{58}$. Warto jednak podkreślić, że mimo takiego stwierdzenia człowiek wprawdzie sięga bezpośrednio Prawdy w wewnętrznym życiu Osób Boskich, ale poprzez konieczne pośrednictwo Syna Bożego ${ }^{59}$. To właśnie On w swoim człowieczeństwie objawia Prawdę (komu Syn chce objawić, Mt 11,27). Człowiek jako stworzenie, jakkolwiek objęte Bożą miłościa, która jest pełnym poznaniem, nie przekracza granicy unii hipostatycznej. Staje się on dzięki uczestnictwu w Prawdzie, bo tym jest biblijne poznanie - przebóstwionym, ale nie Bogiem. Ojciec Paweł Fłorenski streszcza to przekonanie w kilku słowach: Dlatego prawdziwe poznanie - poznanie Prawdy - możliwe jest tylko poprzez przeistoczenie czlowieka, poprzez jego przebóstwienie, poprzez zdobywanie milości jako boskiej istoty: kto nie z Bogiem, ten nie zna Boga. W milości i tylko w milości możliwe jest rzeczywiste poznanie Prawdy ${ }^{60}$. Dzięki temu procesowi ciagłej przemiany człowiek staje się przebóstwionym, czyli zdolnym do ciagłego dynamicznego poznawania niepoznawalnej Tajemnicy Boga, który oczekuje wzajemności ${ }^{61}$. Odpowiedzią na miłość może być tylko miłość, więc ten, który sięga prawdy i Prawdy musi dać świadectwo życiem, całym swoim życiem, myślą mową i uczynkiem. Oznacza to, że człowiek, realizując ideę podobieństwa, wchodzi

${ }^{54} \mathrm{~W}$ przypisie 86 P. Florenski podaje bibliografie literatury rosyjskiej przedstawiającej pojęcia wychodzenia z siebie i wchodzenia obiektu poznania, por. Filar.... dz. cyt.. s. 509.

${ }^{55}$ Por. przypis. 17.

${ }^{56}$ Filar..., dz. cyt., s. 64.

${ }^{57}$ Por. J. Corbon, A. Vanhoye, Poznać, w: Slownik teologii Biblijnej, red. Xavier Leon-Dufour, thum. K. Romaniuk, Poznań 1990, s. 749-753 oraz Poznanie Boga w: Leksykon teologii fundamentalnej, red. M. Rusecki i inni, Kraków 2002, s. 943-948.

${ }^{88}$ Te słowa to cytat z Dialogu o duszy $i$ zmartwychwstaniu, Patrologia Graeca, J.P. Migne, Paryż 1863, tom 46, kol. 96, linia 37.

${ }^{59}$ Człowiek, jako stworzenie pochodzące od Trójjedynego Boga nigdy nie stanie się współistotny Ojcu.

${ }^{60}$ Filar..., dz. cyt., s. 64.

${ }^{61} \mathrm{~W}$ przekonaniu o. Pawła, Bóg jako Bóg zazdrosny, chroni swoje stworzenie i domaga się wzajemności. Por. XIll. List dwunasty. Zazdrość, w: Filar..., dz. cyt., s. 361-374. 
w krąg darów i tajemniczej wymiany: według o. Pawła: Nie można tutaj mówić, co jest przyczyna, a co skutkiem, dlatego że zarówno przyczyna, jak i skutek stanowia strony jednego i tego samego tajemniczego faktu - wchodzenia Boga we mnie jako podmiotu filozofujacego i mojego wchodzenia w Boga jako Prawdy obiektywnej ${ }^{62}$. Bóg poznaje człowieka i człowiek poznaje Boga, poznanie to nie jest tym samym, gdy jest rozpatrywane od strony Trójcy i gdy jest rozpatrywane od strony człowieka. A jednak jest według o. Pawła poznaniem wzajemnym. Bóg raduje się każdym odwzajemnionym aktem miłości, a każdy akt miłości przybliża człowieka do Prawdy, że Bóg jest Miłością. Doniosłość koncepcji o. Pawła Fłorenskiego polega na próbie przedstawienia dynamicznej relacji objawiania się Boga człowiekowi i jego odpowiedzi. Rosyjski filozof wykorzystuje do tego opisu swoje refleksje dotyczące próby poznania życia wewnętrznego Trójcy, aktu-substancji, ponieważ człowiek jest obrazem Boga.

Wywód o. Pawła przedstawia się następująco: człowiek wgłębiając się w siebie i jednocześnie wychodząc poza swoje egocentryczne «Ja», doświadcza siebie nie tylko jako $\mathrm{Ja}(\mathrm{A})$ ale też jako nie-Ja( $\sim \mathrm{A})$. Rosyjski filozof przekonuje, iż człowiek jest istnieniem otwartym, ciągle wchodzącym w siebie $i$ jednocześnie wychodzącym poza siebie ${ }^{63}$. Dlatego poznające $\mathrm{Ja}(\mathrm{A})$ staje się nie-JA( $\left.\sim \mathrm{A}\right)$ i jest współuczestnictwem $w$ drugim, poprzez które staje się w nim Ty(B), czyli ma udział byciu innego. W sobie człowiek doświadcza relacji z drugim (człowiekiem, Bogiem) i ta relacja nie jest ani tym drugim, ani też nie jest nim (człowiekiem) stąd relacja doświadczana $\mathrm{w}$ sobie staje się nie-Ty $(\sim \mathrm{B})$. Ta realność nieTy $(\sim B)$ w człowieku wchodzącym w relację jawi się mu jako nowa rzeczywistość On(C), która zreflektowana i kontemplowana, poprzez zapośredniczenie w Ty, staje się nie-C $(\sim \mathrm{C})$, czyli zobiektywizowanym i przedmiotowym, zapośredniczonym poprzez relację $z$ tym, co zewnętrzne, odzyskanym - «Ja». Nie jest to «Ja» tożsame dosłownie $\mathrm{z}$ pierwotnym «Ja», jest to «Ja» odzyskane poprzez zapośredniczenie w drugim, co schematycznie można przedstawić w następujący sposób:

\section{$\mathrm{JA} \sim \mathrm{JA}=\mathrm{TY} \sim \mathrm{TY}=\mathrm{ON} \sim \mathrm{ON}=\mathrm{ODZYSKANE} \mathrm{JA}$}

Ta misterna konstrukcja, zasada tożsamości numerycznej, oparta jest na prawach logiki, ale z przyjęciem przekroczenia prawa tożsamości rodzajowej $A \equiv A$, ponieważ $w$ odniesieniu do osoby $\mathrm{A} \equiv \sim \mathrm{A}$. Przedstawiona wyżej struktura jest zabiegiem metodologicznym zastosowanym po to, aby łatwiej było przyjąć wywód o. Pawła $z$ uwzględnieniem ontologicznie pojmowanej miłości, dzięki której istnienie zyskuje swoją wartość, a człowiek poznaje Boga.

${ }^{62}$ Filar..., dz. cyt., s. 64.

${ }^{63}$ Tylko taka wizja człowieka, nie niszczy jego stałego odniesienia do siebie, innych i transcendencji. Proces ciagłego samopoznania człowieka $\mathrm{i}$ wchodzenia $w$ relacje jest ciagłym dynamicznym ruchem, w czasie i przestrzeni. 
Zgodnie $\mathrm{z}$ przekonaniem o. Pawła, bycie człowieka, jego istnienie to dynamiczna wymiana darów, której nie sposób objąć w statycznych opisach. Dlatego jedno życie duchowe zapodmiotowione w «Ja» musi być dostrzegane i opisywane w różnych aspektach, pod różnymi kątami. Boża miłość jawi się poznającemu ją w sobie podmiotowi najpierw poprzez Prawdę - Życie duchowe jako wychodzace z Ja, majace swój ośrodek w Ja, jest Prawda. Bóg zaproszony wchodzi w życie człowieka i jest to: Postrzegane jako bezpośrednie działanie drugiego [wtedy] jest ono Dobrem. Dobrem, które przemienia i poprzez człowicka przyjmującego dary Trójjedynego, może być z zewnątrz postrzegane i: Kontemplowane przedmiotowo przez trzeciego, jako promieniujace na zewnqtrz [wtedy] jest Pięknem $^{64}$. To postrzeganie zewnętrzne według o. Pawła może być dwojakiego rodzaju. Po pierwsze człowiek postrzega w sobie piękno, ponieważ odkrywa w sobie łaskę, niezasłużony dar, według którego żyje. Jednocześnie ci, którzy postrzegają jego bycie, dostrzegają to wewnętrzne piękno, taki człowiek po prostu jest piękny pięknem, którego nie można zniszczyć ani upodlić, ponieważ przez nie objawia się Piękno, a poprzez nie Dobro i Prawda ${ }^{65}$.

Wróćmy teraz do podstawowego pytania omawianego problemu. Jak człowiek doświadcza Bożej objawiajqcej się światu milości? Rosyjski uczony konkluduje: Prawda objawiona jest milościa. Milość urzeczywistniona jest pięknem. Urzeczywistniona miłość poprzez Prawdę, Dobro i Piękno to chrześcijańska praxis $(\pi \rho \hat{\alpha} \xi\llcorner\varsigma)$ w każdej dziedzinie życia, od poznania intelektualnego po przeżycie mistyczne. Praxis ( $\pi \rho \hat{\alpha} \xi\llcorner\varsigma)$, którą człowiek realizuje poprzez akty miłosierdzia wobec siebie, innych i świata. To jest jedyny sprawdzian prawdziwości przebywania w obecności Boga. Jedyny sprawdzian, czy: moja miłość jest działaniem Boga we mnie i moim dzialaniem w Bogu; Czyli faktycznie to wzajemne oddziatywanie jest zasada mojego zjednoczenia z Boskim życiem i bytem, tzn. z prawdziwa miłościa, albowiem bezwarunkowa prawdziwość Boga objawia się właśnie $w$ miłości ${ }^{66}$. Oznacza to, że prawdziwą miłość można poznać tylko przez miłość, jakkolwiek różne jej aspekty możemy poznawać poprzez Dobro, Prawdę i Piękno.

Ostatecznie można zakończyć ten wywód zdaniem pojawiającym się na końcu matematycznych dociekań, co bylo do otrzymania.

${ }^{64}$ Filar..., dz. cyt., s. 64.

${ }^{65}$ Ojciec Paweł podsumowuje przedstawiane wywody w jednej krótkiej formule: „«Prawda, Dobro i Piękno». Ta metafizyczna triada nie mieści w sobie trzech różnych zasad, lecz jedna", Filar..., dz. cyt., s. 64. Wspomniany już we wprowadzeniu H.U. von Bathasar zastanawiając się nad wzajemnymi relacjami Dobra, Prawdy i Piękna stwierdza: „Prawda, dobro i piękno są tak bardzo transcendentnymi cechami bytu, że można je pojąć tylko wzajemnie w sobie i wzajemnie przez siebie". Podstawy tegoż pojmowania podaje w: Teologika, t. 1, Prawda świata, Kraków 2005, s. 200-208, cytat s. 207.

${ }^{66}$ Filar..., dz. cyt., s. 64-65. 
W rozproszonym, zatomizowanym i pełnym sprzeczności świecie, wizja rzeczywistości o. Pawła A. Fłorenskiego jawi się jako spójna i przekonywująca. Oczywiście koniecznego kroku w stronę aktu wiary musi dokonać każdy indywidualnie. Rosyjski teolog i filozof, jako że wychodzi w swoich dociekaniach od ludzkiego doświadczania świata i transcendencji, uwzględnia ten aspekt w swojej koncepcji. Przyjęcie koniecznych warunków poznania Bożej Trójjedynej miłości prowadzi do faktycznego poznania Prawdy, Dobra i Piękna. Człowiek jako podmiot poznający, który potrafi wyjść poza swoje egocentryczne 'Ja' dąży do prawdy, działa dobro ${ }^{67}$ i jawi się jako piękny w tym działaniu. Tylko w ten sposób ma udział w Synu, który jest współistotny co do bóstwa Ojcu i Duchowi, a co do człowieczeństwa - nam ludziom.

\section{NOTA BIBLIOGRAFICZNA}

\section{Paweł Aleksandrowicz Florenski [Павел Александровнч Флоренский]}

Urodził się w styczniu 1882 roku, zmarł rozstrzelany niedaleko Leningradu 8 grudnia $1937 \mathrm{roku}^{68}$. Był rosyjskim prawosławnym księdzem, mężem i ojcem, teologiem, filozofem, matematykiem i naukowcem w dziedzinie nauk przyrodniczych, został nazwany Leonardem da Vinci Północy. Swoją młodość spędził w Azerbejdżanie w rodzinnej atmosferze przepełnionej afirmacją kultury europejskiej a szczególnie jej osiągnięć naukowych i artystycznych. O tego ducha jego wychowania dbała szczególnie jego matka Olga Saparowa, potomkini gruzińskiej arystokracji i ojciec Aleksander Fłorenski, inżynier budujący drogi żelazne na Kaukazie. Swoją szkolną edukację rozpoczął w gimnazjum w Tbilisi i kontynuował ją dalej w Moskwie. Studiował równocześnie matematykę i filozofię na Uniwersytecie Moskiewskim. W 1904 odmówił przyjęcia asystentury na tymże Uniwersytecie i rozpoczął studia w Siergiejew Posad, by ostatecznie zostać docentem Katedry Historii Filozofii Moskiewskiej Akademii Duchownej. Jego główna praca to Filar $i$ podpora prawdy. Próba teodycei prawostawnej $w d w u n a s t u$ listach. Tytuł nawiązuje do Pierwszego Listu do Tymoteusza, a sama książka jest refleksją zgłębiającą tematy wiary, Boga, który jest Miłością, Kościoła, człowieka, eschatologii i mądrości. Po rewolucji październikowej o. Fłoren-

${ }^{67}$ Człowiek działający dobro, poznaje prawdę i jest piękny, w szczególny sposób widzi tę prawdę w postawie starca Izydora, któremu poświecił książkę Sól ziemi, tłum. H. Paprocki, Białystok 1996.

${ }^{68}$ Data ta długo nie byla znana - dopiero po otworzeniu archiwów NKWD udal się odnaleźć odpowiednie dokumenty. Źródło: Internet, fotokopie nakazu rozstrzelania. 
ski dodatkowo rozpoczyna pracę jako naukowiec i inżynier, nie zdejmując swojego stroju duchownego. Między innymi kieruje laboratorium związanym $\mathrm{z}$ badaniami nad elektryfikacją, ma posadę w Katedrze Analizy Przestrzeni Uniwersytetu Moskiewskiego. Jeszcze przed rewolucją napisał pracę o geometrycznej interpretacji relatywistycznej teorii względności Alberta Einsteina, ale można powiedzieć, że ciaggle myślał o takiej wizji świata, która połączy w jedno matematyczny, fizyczny i humanistyczny, jak również transcendentalny punkt widzenia. Pragnął przekonać wszystkich ludzi nauki, że naukowe widzenia świata domaga się rozszerzenia o moralny i transcendentalny wymiar rzeczywistości.

Pierwszy raz aresztowano go w 1925 roku następnie 1933, wtedy został skazany na dziesięć lat obozu pracy. Później został przeniesiony do łagru założonego w starym klasztorze na Wyspach Sołowieckich na Morzu Białym, tam dalej kontynuował badania nad pozyskiwaniem jodu z glonów. Rozstrzelano go dnia 8 grudnia 1937 roku dwadzieścia kilometrów od Sankt Petersburga, w tamtym czasie Leningradu.

Przez całe swoje życie o. Paweł Aleksandrowicz Fłorenski, spadkobierca myśli Atanazego i Ojców kapadockich, rozmyślał i pracował nad definicja Bożej Miłości, ponieważ miłość i akceptacja są tym, czego ludzie najbardziej potrzebują w rozproszonym świecie, a szczególnie potrzebują Miłości, której można doświadczyć poprzez akt Bożego stworzenia. To, co było najbardziej charakterystyczne dla o. Pawła Fłorenskiego to jego medytacyjne spojrzenie na całość w aspekcie jedności tego, co jest i jest poznawalne na sposób naukowy, estetyczny czy moralny. Tylko przy akceptacji tych wszystkich trzech dróg razem, możemy doświadczyć Bożego aktu kreacji i związanej z tym jego Miłości69. Ojciec Paweł Fłorenski jest przedstawicielem filozoficznego monizmu (wszystkie rzeczy i każda relacja są stworzone przez Boga i od Niego pochodzą), jednak w swoich pracach badawczych nie znosi napięcia panującego pomiędzy różnymi rodzajami poznania aktu stworzenia świata. Zasadą pozwalającą zrozumieć różnorodność zjawisk występujących w świecie jest tkwiący w nich porządek matematyczny, a jeszcze głębiej tkwi w niej piękno, jakie się w tej rzeczywistości przejawia. To prowadzi o. Pawła bezpośrednio do kategorii dobra. Natomiast dzięki medytacji nad pięknem i dobrem dochodzi się do prawdy. Dobro, piękno i prawda są potrójną drogą ku odkryciu, że Bóg jest miłością - i On jest podstawą istnienia świata $i$ wszystkich praw w nim panujących. Ostatecznie człowiek może tu i teraz powiedzieć, wbrew doświadczanemu cierpieniu i rozproszeniu wartości moralnych, że pierwszym i absolutnym początkiem jest miłość Boga do

${ }^{69}$ Ojciec P.A. Fłorenski był przekonany, że prawa matematyczne i prawa natury są w takim samym stopniu oknem na nieskończonośc jak piękno odwróconej perspektywy w ikonach. I, co ważne, to s a mo piękno objawia się w życiu starca Izydora, którego dzieje opisał w książce Sól ziemi (pokreślenie autorki). 
swego stworzenia, a piękno jest odbiciem jaśniejącej prawdy. Natomiast uczony, przykładowo, kontemplując piękno i prawdę w swoich koncepcjach naukowych rozpoznaje to światło po tym przeświecającym blasku. Idąc tą drogą za o. Pawłem Fłorenskim możemy powiedzieć, że Boża miłość ukazuje się poprzez prawdę, piękno i dobro w stworzeniu. Ojciec Paweł jest bardzo podobny w swoich refleksjach i wnioskach do innego teologa, Hansa Ursa von Balthasara. Obaj mówią i przekonują, że pierwszą zasadą w akcie stworzenia jest miłość, którą możemy rozpoznać poprzez piękno, prawdę i dobro w świecie i przez ludzkie wzajemne relacje.

\section{SUMMARY}

\section{To Discern Uncreated Love Through Beauty, Good And Truth In The Scattering World, According To Father Pavel Alexandrovich Florensky}

Physical research shows us that our world is more and more scattered. This experience of the physical dispersion or the disappearance of what seemed to be permanent is also transferred into the world of values. The hierarchy of values generally accepted in the past yields to dispersion. Sensible references to the act of creation as God's work also disappear. Emphasis is placed on the temporal beginning of our Universe (Big Bang) and people do not think of the ontological (en arche) or theological primeval beginning. How should we to rebuild a uniting vision of the world? It seems useful to appeal to father Pavel Alexandrovich Florensky, a representative of Orthodox theology. He thought over and worked on the definition of God's Love all his life. because it is love and acceptance that people really need in a scattering world, especially the Love, which we experience in the act of creation. What was characteristic of father Pavel was his meditative view on the overall unity of what is and is cognizable in the scientific, aesthetic or moral mode. It is only in those three ways taken together that we can recognize God's creation and His Love. He is very similar in his approach and conclusions to another theologian Hans Urs von Balthasar. They both say together that first principle in the act of creation is love and we can recognize it through the Beauty, Truth and Good in the World and people's relations.

\section{Key words:}

Pavel Florensky, good, truth, beauty, homoousion, person 